\begin{tabular}{rr}
\hline \hline 821.163.41.09:398 \\
https://doi.org/10.18485/msc.2018.47.2.ch6
\end{tabular}

Саша Д. КНЕЖЕВИЋ*

Универзитет у Источном Сарајеву

Филозофски факултет Пале
Оригинални научни рад

Примљен: 11. 12. 2017.

Прихваћен: 27. 12. 2017.

\title{
ЕЛЕМЕНТИ КАРНЕВАЛА У ПЈЕСМАМА И ПРИПОВИЈЕТКАМА ТЕШАНА ПОДРУГОВИЋА
}

\begin{abstract}
У раду ћемо покушати показати да се у пјевачко-приповједачком опусу Тешана Подруговића могу пронаћи елементи карневализације који се не сусрећу код других епских пјевача. До сада су се проучаваоци доста штуро бавили елементима хумора у дјелима за која је Вук Караџић утврдио да их је чуо од знаменитог Гатачког пјевача. Тешан Подруговић није пјевао о догађајима из свог времена, него је искључиво препјевавао старије пјесме, а један од елемената оригиналности и поетске детерминације његовог опуса у односу на познате варијанте јесте управо елемент карневализације, поготово у лику његовог омиљеног јунака Марка Краљевића.

Кључне ријечи: Тешан Подруговић, пјевач, пјесме, приповијетке, карневал, Марко Краљевић, витешки роман.
\end{abstract}

У првом помену својих пјевача у Предисловију Народној српској пјеснарищи из 1815. године Вук Караџић (1815: 7) благодари „за нове юначке сльепцу Фїлїпу Вишньићу (изь Медьаша оть Бїельине); а за све остале юначке Тешану Подруговићу изь Херцеговине". Након тога, а закључно са Рачуном, Вук успоставља редосљед којем остаје досљедан до краја свог живота, а према коме је Тешан Подруговић његов омиљени и најбољи пјевач. Заправо, Тешан Подруговић је и први пјевач којег Вук ангажује да од њега записује пјесме плаћајући му „на дан, колико му треба да може живети” (Караџић 1986: 394), а то је било онолико колико је у вароши могао зарадити од трске коју би за један дан у риту исјекао. Скоро невјероватно дјелује да за потоњих пола вијека Караџић неће наићи на бољег пјевача, нити казивача српских епских народних пјесама, а да је притом још од растанка са Подруговићем и сусрета са Филипом Вишњићем, на различите начине добављао најзнаменитије међу њима или је преко својих сарадника од таквих добијао пјесме.

*knezsa@yahoo.com 
Премда је у науци далеко већи број студија посвећен Филипу Вишњићу и Старцу Милији, Тешан Подруговић се, као својеврсна културолошка детерминанта у принципу, по Вуком успотављеном законоправилу, у свакој врсти набрајања или описивања епских пјевача ставља на прво мјесто. Томе је свакако у великој мјери допринијела и постхумно објављена студија Владана Недића Вукови певачи (1990: 17), чија прва реченица гласи: „Певач кога је Вук највише ценио - стављајући га испред Филипа Вишњића и Старца Милије - заслужује посебан разговор”. Упркос томе, да и не постоји сумња у Вукову процјену и општеприхваћени суд, Тешан Подруговић никада у српској науци није добио монографију у којој би његов немали опус био у цјелости истражен и истумачен, за разлику од њговог омиљеног јунака који је био „предметом бројних, више-мање озбиљних студија” (љубинковић 2010: 252).

Као што је случајан и посве чудесан био сусрет Тешана и Вука суштински су се ненамјерно срели и Тешан и Марко. У Подруговићевом забиљеженом опусу највећи број пјесама, чији јунак није Краљевић Марко, тематски је везан за хајдуке и ускоке. Вукова (1986: 394) забиљешка нас подсјећа да је Тешан знао ,још најмање сто јуначки пјесама, све оваки, као што су ове, које сам од њега преписао, а особито од којекаки приморски и Босански и Ерцеговачки ајдука и четобаша", дакле оне су представљале апсолутну већину његовог пјевачког опуса. Сасвим је природно и логично да је свој пјевачки стил формирао управо на њима, а да су све друге пјесме, формално и формулативно, спјеваване под њиховим утицајем. Отуда је разумљиво да је чак и легендарну пјесму Наход Симеон, спјевану и до њега пјевану по хагиографском предлошку, иновирао у, свом пјевању, у приличну пјесму. Набрајајући потезе којима Подруговић стару сљепачку варијанту прилагођава свом стилском изразу, Светозар Матић (1958: 647-648) показује како је „песник од хагиографије, од светачког житија, направио помало јуначку песму”. У овом исказу нам је најзначајније да и Матић суштину те трансформације препознаје у чињеници да је Тешан Подруговић био пјесник.

Када говоримо о највећим међу Вуковим пјевачима, сваку врсту поетске анализе неопходно је започети ставом да су они били пјесници. Само пјесник је могао чак и најгору пјесму да препјева онако лепо по реду, као што су и остале юегове песме, не зато што је познавао епске формуле и устаљене изразе, него стога што је посједовао изванредан пјеснички дар којим је живот претварао у пјесму. Уосталом, општеприхваћени редосљед Вук (1986: 394-395) поентира посљедњом реченицом свог мини-есеја о Подруговићу: „Његова је свака песма била добра, јер је он (особито како није певао, него само казивао) песме разумевао и осећао, и мислио је, шта говори.” Овај суд Вука Караџић даје на пунољетству свога сакупљачког рада, свјестан да је и једна добра пјесма квалификатив да се неки гуслар именује пјевачем. Своју процјену зналачки поткрепљује са три фундаменталне одреднице разумијевање, осјећање и мишьење.

Сходно овој премиси лако се може извести суд да је Подруговић разумијевајући епску народну пјесму, користећи се сопственим истанчаним осјећањем за њене законитости, према сопственом мишљењу у стихови- 
ма давно прије сатворени епски лик Марка Краљевића преиначио у јунака сопствене пјесме. До Тешана Подруговића је стигао јунак који је по свему био „жив одраз свег народа” (Томазео 1982: 230), онај кога Гете (1982: 153) пореди са Херкулом и Рустаном, јер је „највећи и најјачи од свих српских јунака, безграничне снаге, неумитан и збором и твором.” Марко је требао пјевача који ће га пјеснички избрусити у цијелу и јасну слику, уједно бескрајно комплексну и савршено јасну. У овоме се огледа она полифонија коју Бахтин сматра једним од најзначајнијих постулата поетике Достојевског, која je, дабоме, примарно посљедица комплексности епског лика Марка Краљевића код које Ненад Љубинковић (2010: 252) указује на „бар четири препознатљива, одвојива слоја:

1.Епска, ритерска легенда о Краљевићу Марку - типа француских chansons de geste, византијских епских песама, средњовековних романа попут Александриде, или Романа о Троји, староруских историјских песама XVI и XVII века, итд.

2.Митолошки слој легенде [...]

3.Лимитрофни облик [...]

4. Марко државотворач и слободоносаи [...]"

За наше истраживање најзначајни је свакако први слој којим се у извјесној мјери наш јунак приближава јунацима и свијету витешког романа, јер се према Бахтину (1989: 271) ,у том чудесном свету остварују подвизи, у којима се прослављају сами јунаци, и којима они прослављају друге”. Марко Краљевић Тешана Подруговића је јунак чији подвизи најчешће и јесу подвизи за другог, заточника херојства за туђег цара, што се може образложити сличношћу Бахтиновог (1989: 272) хронотопа „чудесни свет у авантуристичком времену”, који те пјесме дијеле са витешким романом. Намјерним епским удаљавањем Марка од историје он постаје јунак пјесме и пјесама о индивидуалном јунаштву на част колектива, чиме наликује јунацима витешког романа који „су индивидуални, а уједно представници” (Бахтин 1989: 271).

Подруговић лик Марка Краљевића ствара елементима онеобичавања којима га до крајности помјера од његовог стварносног историјског прототипа. Он то првенствено чини описима Маркове одјеће која ничиме не подсјећа на одјећу краља и витеза:

Па припаса сабљу оковану, И пригрну ћурак од курјака, А на главу капу од курјака, Привеза је мрком јеменијом; Па узимље копље убојито

(Караџић 1988: 186)

Те облачи на се одијело:

А на плећи ћурак од курјака, А на главу капу од курјака; (Караџић 1988: 286) 
Јасно је уочљиво да у опреми Марка Краљевића доминирају елементи карневалске маске зооморфног типа ${ }^{1}$ познате у карневалској пракси. Потпуно неочекивано национални јунак се на овај начин непосредно може довести у везу са специфичним ликовима обешењака, лакрдијаша и луде које у средњем вијеку његују „мали фолклорни и полуфолклорни облици сатиричног и пародијског карактера" (Бахтин 1989: 277). Подруговић индивидуализује епског јунака, додјељујући му номинално комичне елементе чије се суштинско значење заправо огледа у чињеници да је његов Марко стално само маска стварног јунака јер ,samo postojanje tih likova nema direktno, nego ima preneseno značenje: njihova spoljašnost, sve što čine i govore, nema direktno i neposredno nego prenosno, ponekad suprotno značenje, ne treba ih shvatiti bukvalno, nisu ono što predstavljaju" (Бахтин 1989: 278). Та игра у коју Подруговић свјесно увлачи своје слушаоце резултирала је тиме да је лик Марка Краљевића у српској култури онај којег је насликао гатачки подругљиваи, јер је он створио заводљиву и изванредно сценичну представу која код реципијената ствара симпатију засновану на препознавању у различитости.

Да спољни изглед Марка Краљевића није формулативна особина нашег пјевача уочавамо компарацијом са описима других јунака чија је опрема стереотипна, као на примјер она у коју Џафербеговица опрема свога господара роба драгокупа:
На плећи му удара кошуљу
До појаса од чистога злата,
Од појаса од бијеле свиле;
По кошуљи зелену доламу,
На којој је тридесет путаца,
Свако пуце од по литру злата
А на главу калпак и челенке,
Један калпак, девет челенака
(Караџић 1987: 18)

Грујица је хајдук који се у народној епској пјесми диче чудним одијелом, које код Подруговића носи Иво Голотрб:

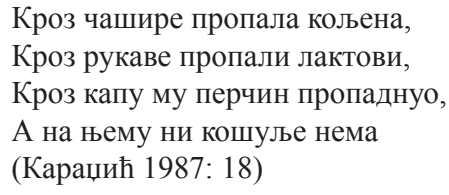

Овдје је у питању тип лажне маске најпознатији по пјесми „Женидба Душанова". Маркова одјећа није маска те врсте, она је маска његовог епског лика, напрема историјском прототипу. Када ситуација и природа пјесме просто налажу да јунак не може бити у њу обучен, као у пјесми „Женидба Марка Краљевића" Подруговић то рјешава врло прагматично једним стихом:

\footnotetext{
${ }^{1}$ Типологија маски преузета је према: Сувајџић 2005.
} 
Спреми Марко себе и Шарина

(Караџић 1988: 244)

У опису другог великог Вуковог пјевача опремање Марково за исту прилику изгледа потпуно друкчије и крајње стереотипно за дату прилику:

Кад с' обуче Краљљевићу Марко,

Уд’ри чоху и уд’ри кадифу,

И на главу калпак и челенку

И на ноге ковче и чакшире

(Караџић 1987: 170)

Заправо, нама сцена из пјесме „Сестра Леке капетана” дјелује као пародирање, јер опис опремања који је успоставио Тешан Подруговић посматрамо као прворазредан. Колико Милија не разумије епског Марка Краљевића показује и то што га други опремају, па чак опремају и његовог коња, а врхунац разликовности проналазимо у стиховима испијања вина:

Један даше коњу од мегдана,

Крвав коњиц до ушију дође,

Други попи на походу Марко,

Крвав марко до очију дође.

(Караџић 1987: 170)

Отуда и не чуди што Милош упозорава слуге да му не прилазе, јер је можда „љутит” или „пијан”. Подруговићев Марко није пијаница иако вино пије као оријаш:

Не пије га чим се вино пије,

Већ леђеном од дванаест ока.

(Караџић 1988: 284)

Он јелом и пићем пантагруеловски поправља вријеме, једење и пијење за Марка заиста представљају побједу над свијетом (Бахтин 1978: 298). Он се у пјесми „Марко Краљевић и Муса Кесеџија” са оног свијета враћа пијући и једући:

„Примакни ми вина и ракије

И дебела меса овнујскога,

И бешкота љеба бијелога;"

(Караџић 1988: 244),

подсјећајући нас да су „Jedenje i pijenje među najvažnijim ispoljavanjima života grotesknog tijela”, чије су најважније особине „otvorenost, nedovršenost, njegova uzajamnost sa svetom" (Бахтин 1978: 297).

Ово нас природно упућује на другог и друкчијег Подруговићевог јунака - Међедовића. Изданак медвједа и човјека свакако представља савршен примјер недовршености, док исконски однос са природом потврђује његову узајамност са свијетом, а његова отвореност за ново, друго и друкчије је еле- 
ментарни извор свих његових недаћа, али и авантура, на којима ова бајка и почива. Он за опкладу поједе храну припремљену за стотине људи, а могао је и још да је претекло, а након симболичног крштења једе као човјек. Гротескна слика разјапљених чељусти које гутају све пред собом није дата само Међедовићу, него и он сам постаје њихова жртва. „Чоек онај сијући жито заборави за Међедовића, и узме га један пут са житом у шаку, те метне у уста. Међедовић се поплаши да га не прогута, те по устима овамо онамо док срећом нађе Један крњав зуб, те се у њему устави и прићути” (Караџић 1853: 21). И сам тај оријаш је са десетак људи и тридесет коња завршио у некој људској глави чија су им разјапљена уста послужила као пећина у коју су се сакрили. Претјеривање је најљепши и најпоетичниији облик лагарије којој је гатачки подругљивац, дакако, био рад. Отуда не чуди да се бајка човјека који је „врло радо којешта весело и шаљиво приповедао” (Караџић 1986: 394) завршава реченицом „И на част вам лаж.”

Када је ријеч о Подруговићевом хумору обично се апострофира пјесма „Марко Краљевић и Љутица Богдан”, у којој је, према Љубомиру Зуковићу (в. 1995: 54), хумор искоришћен као средство да се покаже Маркова људскост којој чак ни страх није стран. Свакако да се недвосмислено слажемо са констатацијом Владана Недића (1990: 34): „Својим хумором Подруговић је обогатио нашу народну епику”, јер је лик Марка Краљевић засновао на елементима хуморног, препознатљивим на моделима из средњовјековне фолклорне баштине и витешког романа. Заправо се фундаментално пјеснички дискурс заснива на ироничном транспоновању традиционалних образаца, што нас подсјећа на оцјену Томе Маретића (1966: 122): „У којем пјесничком дјелу налазимо добра хумора и фине ироније, то је сигуран знак великога пјесничког талента".

Веома битна особина Подруговићевог пјесничког остварења јесте управо балансирање хуморног на граници гротеске, којој се потпуно предаје у „Међедовићу”. Он је мајстор мјере, његови Хајка и Грујица у љубавном заносу се пољубе три-четири пута и мада „Да тко броји, и више би било”, Подруговић се ту зауставља, као што и егзалтацију еротског лудила будимске краљице описује у два стиха:

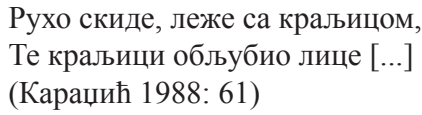

при чему јасно Симеунову слабост правда тиме што га је младог „вино преварило”. Уосталом, и тулумина вина коју Марко вјеша „о ункаш Шарину”, служи као баланс „тешкој топузини”. Занимљиво је да у том дијелу опремања доминира стих „Да не крива ни тамо ни амо”, којим се поново неизбалансираност и недовршеност Подруговићевог Марка оваплоћује тек као маска за јуначки лик који је „наметнуо усменој књижевности као скоро једини могући" (Недић 1990: 31).

Општеприхваћеном мишљењу да је Тешан Подруговић најзначајнији, па и најбољи Вуков пјевач, недвосмислено се мора придодати оцјена да је 
он један од најзначајнијих пјесника Херцеговине и српства у цјелини. Пјесник који је створио цијеле епске ликове од скица које су генерације његових претходника градиле помоћу препознатљивих поетских образаца којима доминирају хумор и ироничан став према свијету који га окружује. Његов осебујни пјеснички дар заснива се на осјећању, разумјевању и промишљању о ономе о чему је пјевао. Карневалска димензија његовог Марка Краљевића посљедица је разумијевања онога о чему је слушао и промишљања како да та знања вјешто удјене у властиту пјесму. Успио је у томе захваљујући изванредном осјећању мјере за пјесму, њене јунаке и слушаоце.

\section{ЛИТЕРАТУРА}

Бахтин 1967: M. Bahtin, Problemi poetike Dostojevskog, Beograd: Nolit. Бахтин 1978: M. Bahtin, Stvaralaštvo Fransoa Rablea, Beograd: Nolit. Бахтин 1989: M. Bahtin, O romanu, Beograd: Nolit.

Гете 1982: J. W. Goethe, Srpske pesme, Ka poetici narodnog pesništva, Beograd: Prosveta.

Зуковић 1995: Љ. Зуковић, Историјски Краљ Марко и епски Краљевић Марко, Бањалука: Нови глас.

Караџић 1815: Народна србска пјеснарица, Беч: Печатна Јоана Шнирера.

Караџић 1986: В. С. Караџић, Српске народне пјесме 2, Београд: Просвета.

Караџић 1988: В. С. Караџић, Српске народне пјесме 3, Београд: Просвета.

Караџић 1986: В. С. Караџић, Српске народне пјесме 4, Београд: Просвета.

Караџић 1853: Српске народне приповијетке, Беч: Штампарија јерменског манастира.

Љубинковић 2010: Н. Љубинковић, Трагања и одговори, Београд: Институт за књижевност и уметност.

Маретић 1966: T. Maretić, Naša narodna epika, Beograd: Nolit.

Матић 1958: С. Матић, Поговор, Српске народне пјесме 2, Београд: Просвета.

Недић 1990: В. Недић, Вукови певачи, Београд: Рад.

Сувајџић 2005: Б. Сувајџић, Јунаци и маске, Београд: Друштво за српски језик и књижевност Србије.

Томазео 1982: N. Tomazeo, Prostrana svjetlost vedroga neba, Ka poetici narodnog pesništva, Beograd: Prosveta. 
Саша Д. Кнежевић

Saša D. Knežević

THE ELEMENTS OF CARNIVAL IN THE TEŠAN PODRUGOVIĆ'S POEMS AND SHORT STORIES

(Summary)

In this paper we will try to show that in the poems and short stories told by Tešan Podrugović can be found many elements of carnivalization which could not be found in the works of other epic singers. Until now the researchers have been vaguely focused on the elements of humor in the works for which Vuk Kradžić claimed he had heard from the well-known singer from Gacko. Tešan Podrugović in his poems was not telling about events from his own period, but exclusively rendering in verse the older poems, and one of the elements of originality and poetical determination of his works, in comparison to the other known variants, is exactly the element of carnivalization, especially in the character of his favorite hero, Marko Kraljević (Prince Marko). 